\title{
The production of the splash phenomenon, as a way of dissipating the energy of a gravitational wave
}

\author{
Yevhen Horbatenko \\ NAS Institute of Hydromechanics of Ukraine \\ M.Kapnist str. 8/4, Kyiv, Ukraine, 03057 \\ gorbatenko.eg@gmail.com, orcid.org/0000-0002-6597-3036
}

Received 27.05.2019, accepted after revision 06.10.2019

https://doi.org/10.32347/uwt2020.10.1802

\begin{abstract}
Investigations are aimed at revealing the conditions for the generation of a Splash wave phenomenon by a submerged breakwater, as having a particularly effective form of wave energy dissipation. On the basis of a wide range of wellknown theoretical studies of wave transformation over bottom inhomogeneities, the expediency of laboratory experiments on physical models is shown as a method that allows taking into account the peculiarities of the influence of targeted turbolization of the water flow. Numerous experiments on physical models have shown the possibility of the occurrence of such a phenomenon over a system of bottom inhomogeneities and the rationality of further scientific search. However, the effect is achieved when certain parameters of many independent variables (significant and represented in a wide range of factors) are combined. This circumstance makes a positive solution of the problem rare in nature.

In view of the multifactority of the hydrodynamic process under investigation, an analysis of the theoretical premises was carried out, which allowed us to concentrate on a new variant of the solution of the problem posed - a single breakwater with a special crest design. The version of a "box" type breakwater was taken.as a basis But part of the wave energy quenched in it is directed to quenching another part of the energy of the wave flow passing over the top of the breakwater. The task was to find the location, shape and size of the opening in the top. Two versions were investigated: in the form of a perforation and in the form of a slit located along the breakwater. The last version showed its superiority and this result allowed to proceed to the solution of the next problem, the search for the most effective of the of the
\end{abstract}

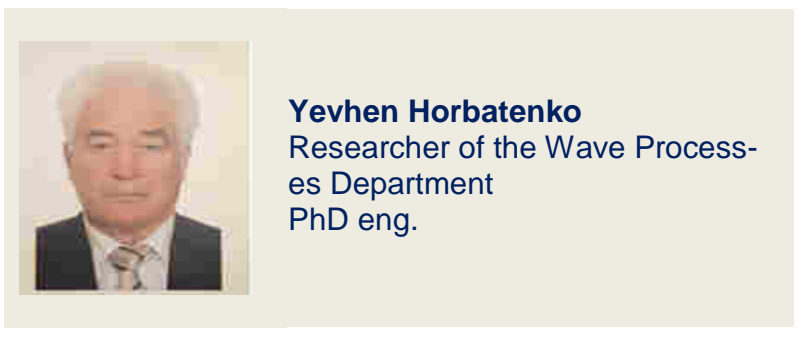

breakwater cavity cross-section.shape. The obvious direction of the search was the effect of a curvilinear wave-breaking wall of the embankment. Instead of the vertical face under the "visor" (that is, under the horizontal plane of the top surface) previously accepted in the studies, two schemes for calculating the surface curves, differing from each other in radius and length, are studied. The size of the slit in the "visor" varied. The conditions and prospects for the development of Recommendations for the design of the submerged breakwater of this type are described.

The urgency of the solution of the problem lies in the broad perspective of the use of submerged breakwaters in recreational zones.

Key words: recreational zone, breakwater, wave transformation, energy dissipation, physical modeling, hydrodynamic bench.

\section{INTRODUCTION}

Among the structures of coastal hydraulic engineering, submerged submerged breakwater is of particular importance as an object of environmental nature. If the full-profile breakwater is designed to completely Among 
the structures of coastal hydraulic engineering submerged breakwater is of particular importance as an object of environmental nature. The full-profile breakwater is designed to completely dampen the wave, for example, allowing ships to be directly at the pier, but the submerged breakwater is used mainly to protect the beach from erosion. Namely, the beach of recreational areas, where it allows to provide water exchange in the closed water area [1 - 3]. This obvious requirement was underestimated until recently, which led to serious sanitary and epidemic problems [4]. An example of this is the existing system of coast protection of famous resort areas, where quarantine measures are systemic in nature.the wave, for example, allowing ships to be directly at the pier, the flooded breakwater is used mainly to protect the beach from erosion. It is the beach of recreational areas, where it allows to provide water exchange in the closed water area. This obvious requirement was underestimated until recently, which led to serious sanitary and epidemic problems. An example of this is the existing system of coast protection of famous resort areas, where quarantine measures are systemic in nature.

There are many types of designs of submerged breakwaters, both in the form of projects and built, and even more developments in the form of inventions, information about which abounds in the Internet. The matter boils down to the choice of compatibility of performance and cost of construction [5-7].

The experimental studies previously conducted in the laboratory Of the Institute of hydromechanics of NAS of Ukraine were aimed at identifying the possibility of certain designs of submerged breakwater to give the structure the function of not only passive but also active wave annihilation. That is, by means of a certain design solution, to turbolize the wave flow over the structure. Mainly, combinations of free-standing breakwaters with a large variation of the parameters of the structural elements and the planned location relative to each other were studied. Special attention was paid to the systems of two and three breakwaters. The search for the compatibility of the studied parameters led to the pos- sibility of production of the Splash phenomenon in the interference of the incoming and reflected waves.

The functional dependence of the degree of wave annihilation on the parameters of local conditions, the dimensions of structures and their location at this stage of research was presented in a simplified form:

$$
K_{t r}=f\left(d_{,} i_{m} h_{w, ~} \lambda_{r,} Z, L\right)
$$

where: $K_{t r}$ is wave transformation coefficient, $\mathrm{d}$ is water depth at the breakwater (Const), $\mathrm{i}$ is slope of the bottom surface of the water area (Const), $\mathrm{h}_{\mathrm{w}}$ is wave height ("before", "above" or "behind" the breakwater), $\lambda_{r}$ is relative wavelength (steep - 10 and somewhat gentle 15), $\mathrm{Z}$ is deepening of the top of the breakwater (in 3 values for each option), $\mathrm{L}$ is distance between the individual breakwaters in the system (in 3 values).

Considering the theoretical assumptions, the solution of the problem can be based on the known provisions [8]. Thus, wave annihilation and wave reflection are studied by the extremal values of the wave surface shape on the approaches to the structure, directly at the structure and behind the structure. The shape of the traveling wave can be described by the following relation:

$$
\begin{aligned}
& \xi=-a \cos (k x-\omega t)-\frac{k a^{2}}{2} \cos [2(k x-\omega t)]- \\
& -\frac{3 k^{2} a^{3}}{8} \cos [3(k x-\omega t)],
\end{aligned}
$$

where: $a$ is wave amplitude, $g$ is acceleration of gravity, $\omega$ is wave circular frequency, $k$ is wave number, $\lambda$ is wave length, $d$ is water depth at the structure, $\chi$ and $z$ are point coordinates, $t$ is time coordinate, $\xi$ is profile shape.

Numerical evaluation of the importance of the members of the right part of the present relation shows that the refinements made to the first member by the second one do not exceed $5 \%$, and by the third one do not exceed $1 \%$. This allows us to exclude them from con- 
sideration as not essential for engineering practice. Using the theory of plane potential waves of finite amplitude at finite depth, we have a relation for the potential velocities of the initial wave:

$$
\phi=\frac{\operatorname{agch}[k(d-z)]}{\omega \operatorname{ch} k d} \sin (k x-\omega t)
$$

Interaction with the structure modifies the waveform and its velocity potential. The ratio of the amplitudes of the original and reflected waves has a physical meaning of the reflection coefficient "Ko". Due to the configuration of its profile, the structure can reflect waves partially to a certain extent. The magnitude of the initial wave amplitude is denoted by " $\alpha$ ", directly at the structure by " $\alpha 1$ ", behind the first obstacle (breakwater) by " $\alpha 2$ ".

The velocity potential of such a wave is equal to:

$$
\begin{aligned}
& \phi_{1}=\frac{\operatorname{agch}[k(d-z)]}{\omega c h k d} \times \\
& \times\left[\sin (k x-\omega t)+K_{0} \sin (k x+\omega t)\right]
\end{aligned}
$$

The structure of an incomplete profile passes part of the wave energy through itself, due to which a residual wave with an amplitude of $\alpha 2$ is formed behind the structure. In this case, the velocity potential is equal to:

$$
\phi_{2}=\frac{a_{2} g \operatorname{ch}[k(d-z)]}{\omega \operatorname{ch} k d} \sin (k x-\omega t)
$$

The ratio $\alpha 2 / \alpha$ characterizes the permeability, and $1-\alpha 2 / \alpha$ is called the annihilation coefficient $\mathrm{Ka}$.

Further consideration of the process should be conducted according to the scheme, which shows that the residual wave with amplitude $a_{2}$ is the initial wave for the second underwater obstacle and repeats the effect of the first obstacle.

The velocity potential of the interfered wave between the obstacles will take the form: $\left.\left.\phi_{3}=\frac{a_{2} g c h[k(d-z)]}{\cdots}\right] \sin (k x-\omega t)+\frac{a_{3}}{\sin (k x+\omega t)}\right]$

(6)

Using the energy approach to the consideration of the process of interaction of waves with the studied system of structures, we state that a part of the wave energy is reflected $\left(\mathrm{E}_{\mathrm{O}}\right)$, a part is extinguished due to friction and is spent on turbulence $\left(\mathrm{E}_{\mathrm{T}}\right)$, but a part passes behind the structure (Eost). The balance equation is as follows:

$$
E=E_{o}+E_{T}+E_{o c m}
$$

The energy of the components of the equation is proportional to the corresponding amplitudes:

$$
E=0.5 \rho g \lambda a^{2}, \quad E_{0}=0.5 \rho g \lambda a_{1}^{2}, \quad E=0.5 \rho g \lambda a_{2}^{2}
$$

This is how the proportion of wave energy extinguished by the structure is quantified.

The idea of spectral representation of a complex excited surface is known, which was first expressed by Peterson [9] and found its expression in the works of Longue-Higgins [10]. Phillips [11] showed that in the highfrequency range of the wind wave spectrum there is an equilibrium region where the spectrum does not depend on wave-forming factors and is determined by physical parameters regulating the continuity of the wave surface. Such simplification would help to solve the problem, but there are many assumptions. The specificity of this work and the lack of necessary technical capabilities determined a simplified approach to the development of research methods.

The study of the wave surface transformation process was carried out under the influence of bottom inhomogeneities in the form of cylinders lying on the bottom of the reservoir. This was in line with the question of the use of mobile structures, which in practice are soft synthetic shells. The designs of such structures are developed at the level of inventions $[12,13]$. Numerous series of experiments 
in the wave basin and tank showed the exceptional complexity of the studied hydrodynamic processes. The pattern of interference between the shells is complex, since the wave with energy losses (and a decrease in amplitude correspondingly) is repeatedly reflected from the next and previous shell. As it is predetermined by the theory, at distance between shells multiple to a half of wavelength the resonance of oscillations, and at non-multiple distances the crush is observed. The phenomenon of crush does not allow us to obtain a numerical solution of the problem.

With a certain combination of parameters of independent variables, that is: the depth of water before the first submerged breakwater; the height of the initial incoming wave and its relative length; the size and ratio of the diameters of the shells, that is, the depth of the top of the breakwaters, as well as their mutual distance from each other, the Splash effect was obtained - the phenomenon of high dissipation of wave energy.

However, in practice, a small probability of a certain combination of wave parameters and multicomponent structure is obvious [14].

The aim of this work was to find a design of a single submerged breakwater that has the ability to generate a Splash effect, which in practice is more likely in a wider range of wave parameters than for a system of submerged breakwaters [15].

The solution of the problem was carried out on the basis of the design of a single breakwater with a top resembling a box-type breakwater [16]. On an intuitive level, it is quite natural to solve the problem by means of a "visor" on the top of the breakwater, which would dissect the wave flow at the top of the breakwater. In this case, the crest of the wave will pass over the breakwater, and the trough of the wave will be under the "visor", where the pressure will increase and the flow as a whole can be turbolized.

The design of the upper part of the breakwater was presented in different versions. So, the box-type chamber can vary in size, shape of the back wall, and the upper plane with a "visor" can have different lengths and perforations. It was adopted a gravitational type base of the breakwater with parameters in some accordance with the current norms [17]. Thus, a clear feature is the strtucture crowning the top of the breakwater. In Fig.1 the initial version (Scheme No.3) and the version having the desired properties (Scheme No.2) are presented.

In contrast to the previous stage of research, the efficiency of the structure depends mainly on the depth of the top of the breakwater, and practically - on the water level in the reservoir.
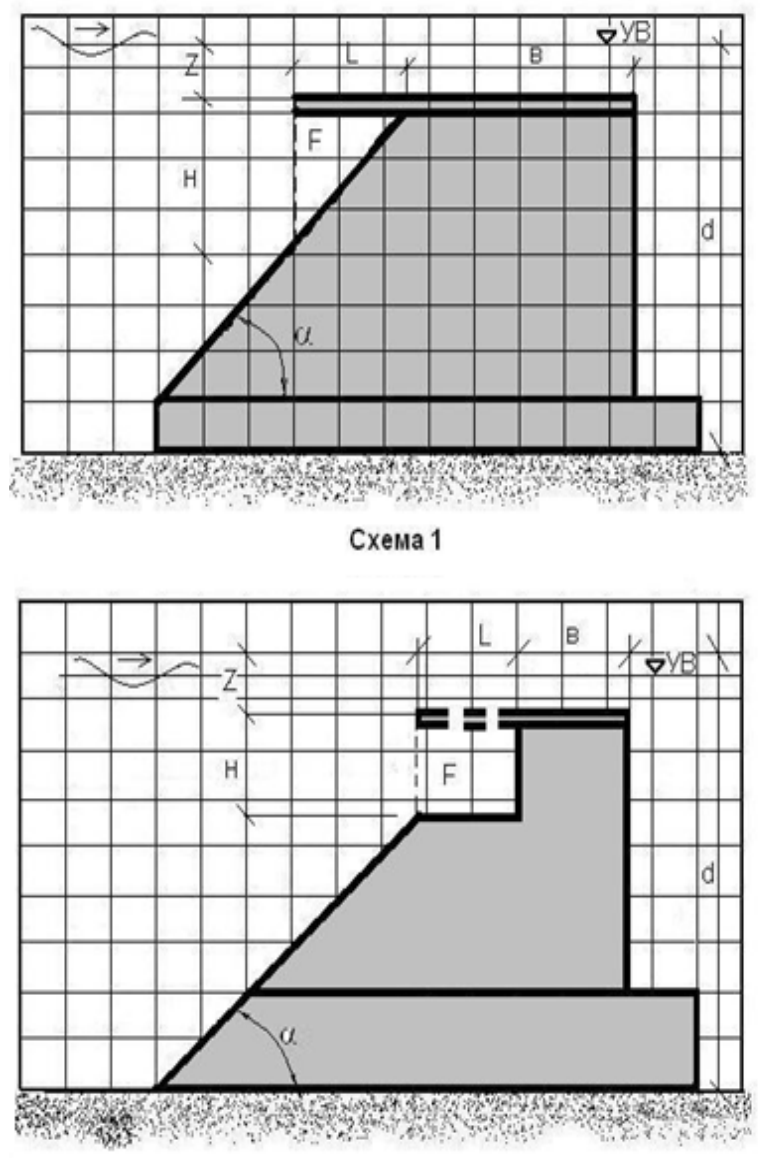

Cxema 2

Fig. 1. The original and the desired version of the construction of the top of the submerged breakwater with a perforated visor

It should be assumed that the sea level may change due to wave positive or negative surge as well as a very real increase in the level of the world ocean. The latter circumstance is particularly important for the designs of traditional monolithic structures. The mode of the 
wave flow is less significant and this may be considered as an advantage of the considered design [18].

Since the studies were exploratory in nature, the basic law of modeling was the inverse relationship between the wave period and the square root of the scale of modeling $[19,20]$. Thus, the wave produced on the hydrodynamic stand in $0.8 \mathrm{~s}, 1.0 \mathrm{~s}$ and $1.2 \mathrm{~s}$ corresponded in nature to the storm wave and two values of slightly more gentle waves ( $\Lambda_{0}=10$ and 15$)$. The studies were carried out in a hydrodynamic tank equipped with a shield-type waveproductor and a wave suppressor in the form of a gentle slope. Video recording and capacitive sensors with the output of information to the PC [21] were used as sensors.

In Fig.2, a photo of a Splash above the top of a single breakwater is presented, which is achieved through a successful choice of shape and location of the perforation.

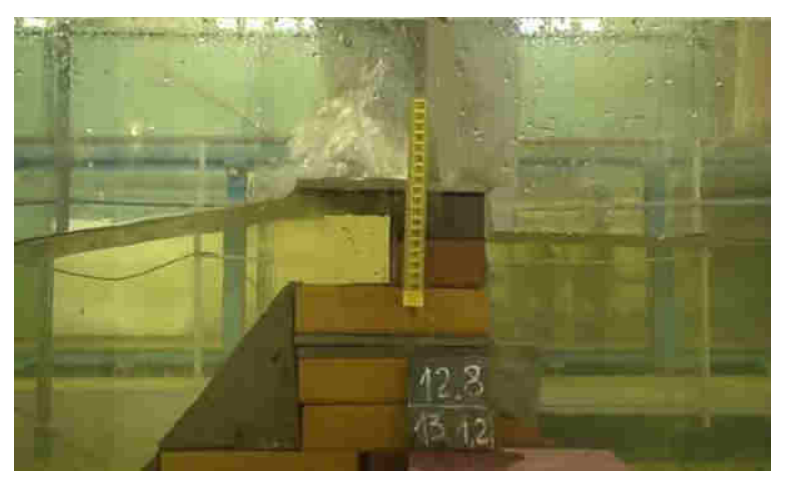

Fig. 2. Splash effect over the top of a single submerged breakwater with perforated visor

Comparing the waveforms recorded in the ports in front of the breakwater and behind the breakwater, we clearly have the fact of significant damping of the incoming wave, where the transformation coefficient reaches 0,8. As shown by a series of experiments, in the framework of the studied parameters of the wave and the structure, the studied design with a perforated visor is the most effective one.

The search for the design of the top for the Splash effect was based on versions of perforation of the upper plane of the top of the breakwater in combination with a certain water level and wave parameters. Special attention was paid to the cavity under the visor. The name of the breakwater type "box" suggests the shape of a rectangular parallelepiped. However, the principle of design of the breakwater wall should be considered in the present design.

The main feature of the study is the testing of models with a curved wall. Two versions are accepted for the test: with a radius of 3.8 $h_{\mathrm{B}}$ (Fig. 3 ) and $4.9 h_{\mathrm{B}}$ (Fig.4). At the same time, the version of perforation in the top in the form of a transverse slit was studied.

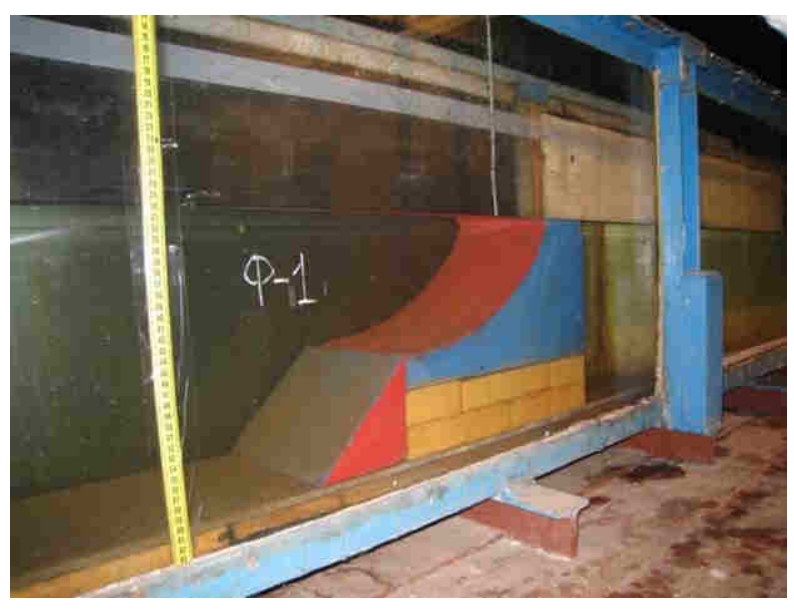

Fig. 3. A version of the design of the submerged breakwater with a steeply curved back wall of chamber that blocks the wave

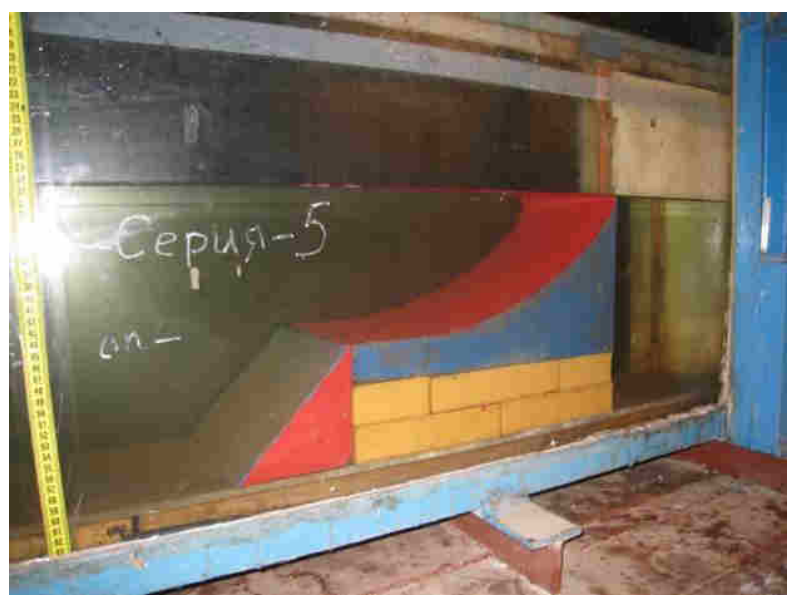

Fig. 4. A version of the design of the submerged breakwater with a gently curved rear wall of the chamber that blocks the wave 


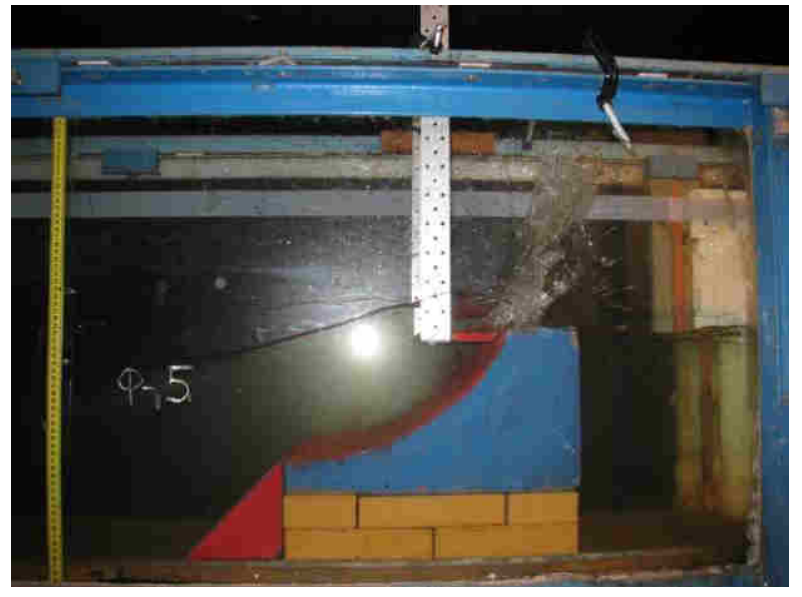

Fig.5. Splash of the significant magnitude over the submerged breakwater with a steeply curved wall

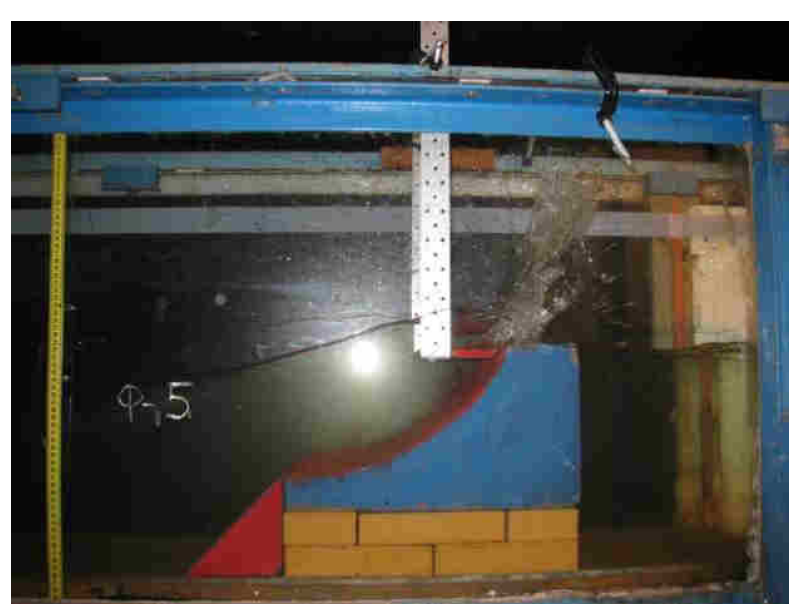

Fig.6. Splash of the less significant magnitude over the submerged breakwater with a gently curved wall

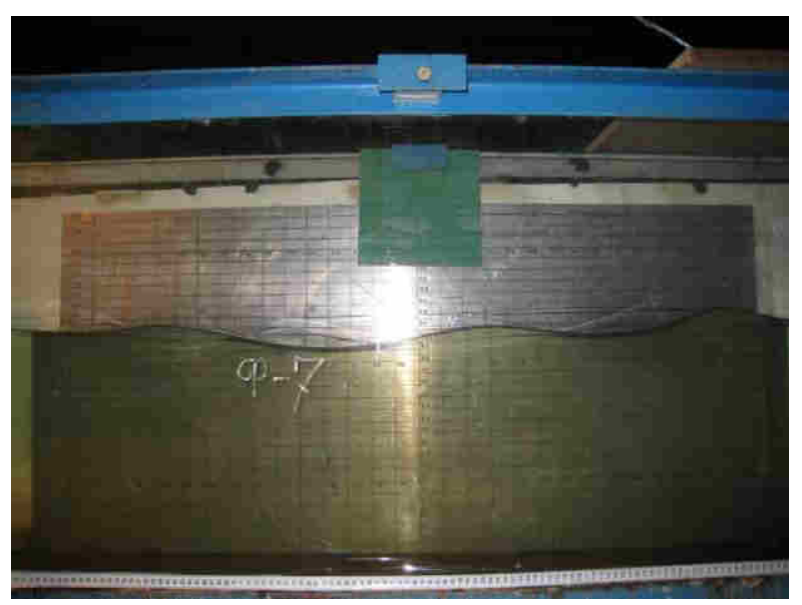

According to the results of the experiments, the steep curvature of the wall and the small size of the slit were found to be more effective. (Figs.5 and 6).

Fixing the height of the transformed wave by the method of photography (as an example) is shown in Fig.7.

The numerical value of the damping energy of the incoming wave, as well as its transformed height, can be accurately determined through a large series of time-consuming experiments with proper technical support of the instrumentation, which will allow to develop Recommendations for design and implementation in practice $[22,23]$.

The author expresses gratitude for the assistance in the preparation and conduct of experiments, processing of research materials and participation in the design of the article to the members of staff of the Institute: Abramova L.P., Bratasyuk I.P., Kudybin I.B., Nikitin I.A., Tereshchenko L.N., Khomitsky V.V., Khizha I.A.

\section{RESULT OF WORK}

It is confirmed that in conditions were complex hydrodynamic processes cannot be subject to accurate theoretical assessment, a physical simulation allows us to assess the performance of the studied design of the submerged breakwater.

It is shown that it is possible to effectively turbolize the wave flow over the top of the breakwater in the form of a Splash phenomenon, which corresponds to a high dissipation of wave energy.

A single submerged breakwater with a perforated visor, unlike a system of submerged breakwaters, is able to work effectively in a wider range of wave flow parameters.

To develop Recommendations for the design and use of the studied structure of the submerged breakwater, it is necessary to conduct a series of experiments with additional proper equipment of the hydrostand and the use of more modern instrumentation.
Fig. 7. An example of fixing the height of the wave by the method of photography 


\section{REFERENCES}

1. Udovik V.F., Mihajlichenko S.Yu., Goryachkin Yu.N., 2016. O vozmozhnom puti resheniya problemy zashity beregov. Sevastopol, Morskoj gidrofizicheskij zhurnal, No 2, 1-36 (in Russian).

2. Fokina N.A., 2008. Rekreacionnaya deyatelnost i abrazionnye processy. Simferopol, Stroitelstvo i tehnogennaya bezopasnost, Vyp.23, 88-92 (in Russian).

3. GOST 17.1.5.02-80. Ohrana prirody. Gidrosfera. Gigienicheskie trebovaniya k rekreacii vodnyh obektov. Moskva, Izdatelstvo standartov (in Russian).

4. Marugin V.M., Spiridonova M.A., 2013. Kvalimetriya morskih pribrezhnyh akvatorij, Sankt-Peterburg, Politehnika, 258 (in Russian).

5. Ivanenko T.A., Vetrova N.M., 2013. Kompleks ekologicheski bezopasnyh tehnicheskih reshenij zastrojki rekreacionnyh zon. Problemy ekologii, No 1, Doneck, DTNU, 89-97 (in Russian).

6. Volkova E.S., 2013. Razrabotka novogo metoda zashity iskusstvennyh territorij ot shtormovogo volneniya. Izvestiya Sochinskogo GU, №2, 7-10 (in Russian).

7. Savchenko V.E., 2018. Sovershenstvovanie konstrukcij beregoukrepitelnyh sooruzhenij. $\mathrm{H}$ Mezhdunarodnaya nauchnaya konferenciya Studencheskij nauchnyj forum - 2018, Rezhim dostupa: http//www.scinceforum.ru, 2 (in Russian).

8. Mak-Kormik, 1985. Preobrazovanie energii voln. Moskva, Energoizdat, 137 (in Russian).

9. Piterson V.D., 1962. Vetrovye volny. Sb. Vetrovye volny, Moskva, Izdatelstvo inostrannoj literatury, 561-583 (in Russian).

10.Longe-Higgins, 1962. Statisticheskij analiz sluchajnoj dvizhushejsya poverhnosti. Sb. Vetrovye volny. Moskva, Izdatelstvo inostrannoj literatury, 129-143 (in Russian).

11.Fillips O.M., 1980. Gidrodinamika poverhostnyh i vnutrennih voln. Leningrad, Gidrometizdat, 320 (in Russian).

12.Copyright certificate 1351988 USSR, 1987. Podvodnoe sooruzhenie, sposob ego montazha i demontazha. E.G. Gorbatenko. Byul.42, opubl. 15.11.1987 (in Russian).

13. Copyright certificate 1145087 USSR, 1985. Ustrojstvo dlya zashchity podvodnyh transhej ot zaneseniya nanosami. Gorbatenko E.G., Homickij V.V., Sokolnikov Yu.N., Kortikov I.A.. Byul.10, opubl. 15.03.1985 (in Russian).
14.Shujskij Yu.D., Vyhovanec G.V., 2017. Sovremennaya dinamika peschanyh akkumulyativnyh form relefa v beregovoj zone Chyornogo morya. SlovakIntern. Scientific Journal (Bratislava), Vol.1, No 11, 22-32 (in Russian).

15.Gorbatenko E.G., Bratasyuk I.P., Sharov V.V., 2015. Mobilnye sooruzheniya $\mathrm{v}$ beregovoj gidrotehnike.Kiev,Podvodnye tehnologii, No 1, 23-32 (in Russian).

16.Chernyshov A.S., 2007. Ekonomikoekologicheskie aspekty ispolzovaniya pogruzhennyh dempfiruyushih platform pri stroitelstve gidrotehnicheskih sooruzhenij. Vesnik Odesskogo GU, Vyp.4, 113-121 (in Russian).

17.SP 277.13425800.2016, 2016. Sooruzheniya morskie beregozashitnye. Pravila proektirovaniya. Moskva, Standartinform, 91 (in Russian).

18.Shahin V.M., Shahina T.V., 2000. Modelirovanie transformacii voln i techenij v pribrezhnoj zone morya.Moskva, Okeanologiya, Vol.40, No 5, 653-657 (in Russian).

19.Shelushinin Yu.A., Makarov K.N., 2019. Problemy i perspektivy gidravlicheskogo modelirovaniya volnovyh processov $\mathrm{v}$ iskazhyonnyh masshtabah. Stroitelstvo: nauka i obrazovanie, T.9, Vyp.2, 1-13 (in Russian).

20.Zommer V.L., 2015. Specifika gidravlicheskih i gidrotehnicheskih nauchnyh issledovanij v laboratorii gidrotehniki i gidravliki. Stroitelstvo: nauka i obrazovanie, No 2, 5, Rezhim dostupa: http://nso-jornal.ru, 9 (in Russian).

21.Kushu, 2018. Problemy i osobennosti proektirovaniya i provedeniya ekspertiz morskih gidrotehnicheskih sooruzhenij. Sochi, Materialy $\mathrm{H}$ Mezhdunarodnoj nauchnoprakticheskoj konferencii, 21-23.05.2018, 1217 (in Russian).

22.Shujskij Yu.D., 2018. Istoriya razvitiya i metodologiya beregovedeniya. Odessa, 456 (in Russian).

23.Shujskij Yu.D., Vihovanec G.V., Pankratenkova D.O., 2019. Osnovni risi antropogennogo vplivu v beregovij zoni Chornogo ta Azovskogo moriv u mezhah Ukraini. Sevastopol, Ukrainskij geografichnij zhurnal, No.1, 814 (in Russian). 


\section{Продуцирование явления всплеска, как способ диссипации энергии гравитационной волны}

\section{Yevhen Horbatenko}

Abstract. Исследования имеют своей целью выявить условия генерации подводным волноломом явления Всплеска, как обладающего особо эффективной формой диссипации энергии волны. На базе широкого круга известных теоретических исследований трансформации волны над донными неоднородностями показана целесообразность проведения лабораторных опытов на физических моделях, как метода, позволяющего учесть особенности влияния целенаправленной турболезации волнового потока. Многочисленные опыты на физических моделях показали возможность возникновения такого явления над системой донных неоднородностей и рациональность дальнейшего научного поиска. Однако эффект достигается при сочетании определённых параметров многих независимых переменных (значимых и представленных в широком спектре факторов). Это обстоятельство делает положительное решение задачи редким в натуре.

В виду многофакторности исследуемого гидродинамического процесса проведён анализ теоретических предпосылок, что позволило сосредоточиться на новом варианте решения поставленной задачи - одиночном волноломе с особой конструкцией гребня. За основу был взят вариант волнолома «ящечного» типа. Но погашаемая в нём часть энергии волны направлена на гашение другой части энергии волнового потока, проходящего над гребнем волнолома.
Задача состояла в поиске места расположения, формы и размера проёма на поверхности гребня. Исследовано два варианта: в виде перфорации и в виде щели, расположенной вдоль волнолома. Последний вариант показал своё превосходство и этот результат позволил перейти к решению очередной задачи - поиску наиболее эффективной формы поперечного сечения плоскости волнолома. Очевидным направлением поиска представился эффект криволинейной волноотбойной стенки набережной. Вместо ранее принятой в исследованиях вертикальной грани под «козырьком» (то есть под горизонтальной плоскостью поверхности гребня) исследовано две схемы расчёта кривых поверхности, отличающиеся друг от друга радиусом и протяжённостью.

При этом варьировался размер щели в козырьке. В статье изложены условия и перспектива разработки Рекомендаций по проектированию подводного волнолома рассматриваемого типа. Актуальность решения вопроса состоит в широкой перспективе использования подводных волноломов в рекреационных зонах.

Ключевые слова: рекреационная зона, волнолом, трансформация волны, диссипация энергии, физическое моделирование, гидродинамический стенд. 